\title{
INFLUENCE OF CONTROL SYSTEMS AND SLACK TIME ON PROCESS INNOVATION
}

\author{
CELLIANE F. PAZETTO ${ }^{1}$ \\ (D) https://orcid.org/0000-0002-7413-1981 \\ SILVANA MANNES ${ }^{1}$ \\ (iD) https://orcid.org/0000-0002-7608-1519 \\ ILSE M. BEUREN ${ }^{1}$ \\ (iD) https://orcid.org/0000-0003-4007-6408
}

To cite this paper: Pazetto, C. F., Mannes, S., \& Beuren, I. M. (2020). Influence of control systems and slack time on process innovation. Revista de Administração Mackenzie, 21 (3), 1-27. doi:10.1590/ 1678-6971/eRAMR200147

Submission: Aug. 19, 2019. Acceptance: Dec. 10, 2019.

Federal University of Santa Catarina (UFSC), Florianópolis, SC, Brazil.

\section{(c) $\mathrm{BY}$}




\section{ABSTRACT}

Purpose: This study analyzes the influence of the interactive and the diagnostic use of Management Control Systems (MCS) and slack time on process innovation in incubated companies.

Originality/value: Organizational characteristics are associated with processes innovation in organizations with contemporary configuration. The study brings evidence to the contrasting findings of the MCS literature with slack time and process innovation.

Design/methodology/approach: A survey was conducted with managers of companies listed on websites of incubators associated with the Associação Nacional de Entidades Promotoras de Empreendimentos Inovadores (National Association of Entities Promoting Innovative Enterprises), obtaining a sample of 106 valid responses. To analyze the data, the Structural Equation Modeling technique was applied to analyze the data.

Findings: The results indicated that the interactive use of MCS promotes slack time at work, and the diagnostic use inhibits its creation. However, slack time was not significantly associated with processes innovation, which reveals a dysfunctional role of the slack. The interactive use of MCS had a significant influence on processes innovation. It is concluded that the interactive use prevails when the purpose is to promote processes innovation, as it favors contacts between different hierarchical levels and learning, while the diagnostic use highlights its relevance by inhibiting the creation of slack time, understood as a dysfunction for not leading to processes innovation. This denotes that the interactive and the diagnostic use of MCS are complementary in incubated companies.

\section{KEYWORDS}

Diagnostic use. Interactive use. Management Control Systems. Slack time. Processes innovation. 


\section{INTRODUCTION}

Although it is recognized that Management Control Systems (MCS) are used to implement innovative strategies, some studies indicate that they tend to restrict innovation (Bisbe \& Otley, 2004), while others advocate that they favor innovation (Bisbe \& Malagueño, 2009; Frezatti, Bido, Cruz, \& Machado, 2017; Lopes, Beuren, \& Martins, 2018). The literature shows several possibilities of design and use of MCS for the implementation of organizational strategy. Therefore, attention should be given to the orientation of the control, which, regarding the use, translates the way managers lead the organization towards the achievement of objectives (Simons, 1995; Henri, 2006).

Among the approaches to the use of MCS, the herein study focuses on the taxonomy Levers of Control, by Simons (1995), being restricted to the diagnostic and interactive use, aiming at the promotion of processes innovation. As the interactive use has a more flexible nature, it is considered more appropriate for evaluating opportunities and strategies of innovation, while the diagnostic use tends to be more restrictive and mechanistic, with greater emphasis on monitoring (Simons, 1995; Demartini \& Mella, 2014). Abernethy and Brownell (1999) investigated the diagnostic and interactive use of budgeting and, as they found greater benefits of the interactive use in the context of change, reiterate the concept brought by Simons (1990) that effective strategy implementation does not influence the importance of control in organizations, but the way control is used.

Lawson (2001) argues that different forms of MCS usage have different implications for organizational slack, whether its creation (which can be stimulated by the interactive use of MCS, seeking to promote interactions and learning) or inhibition (resulting from the diagnostic use of MCS that interprets resource deviations as dysfunctionalities). It is speculated that the diagnostic and interactive uses of MCS may be antecedents of organizational slack. Therefore, high levels of slack are related to high levels of reflection and information, leading to innovation (Sharfman \& Dean Jr., 1997). Organizational resource slack is often addressed in studies to highlight positive outcomes from the excess of organizational resources (Beck \& Beuren, 2015). In the herein study, the emphasis is on slack time, a possible driver of creativity and innovation. In general, the functional aspects of organizational slack are analyzed (Lawson, 2001), but there are contexts in which it can be seen as a waste of resources (Tan \& Peng, 2003). 
Previous studies on organizational slack (e.g., Nohria \& Gulati, 1996; Lawson, 2001; Tan, 2003; Zhor, 2018) reveal a research gap regarding the emphasis on the relationship between organizational resources and innovation. This relationship between resources slack and innovation is complex, as the literature classifies it as a promoter of innovation and a waste of resources (Agrawal, Catalini, Goldfarb, \& Luo, 2018). It is assumed that the relationship between MCS and processes innovation is explained by slack time, as they are exceeding resources that can stimulate organizational creativity and reflect on innovation.

Thus, the herein study aims to analyze the influence of the interactive and diagnostic use of the MCS and slack time on processes innovation, as well as the mediating effect of slack time on the relationship between the use of the MCS and innovation in incubated companies. The relevance of the study is to seek empirical evidence to determine the extent to which the interactive and diagnostic use of the MCS act as predictors of processes innovation and are explained by the slack time in the work of the incubated companies' employees. Moreover, exploring the consequences of using different forms of control in incubated companies is a means of implementing organizational strategy and optimizing its resources.

The incubation process goes through the formulation of the strategy that aims to facilitate the development and implementation of new businesses (Hackett \& Dilts, 2004). In general, entrepreneurs start from innovative ideas and seek to be linked to a business incubator, usually established in technological centers. The business incubator offers the incubated several facilities, such as strategic guidance, monitoring and support system, a system that aggregates resources in order to favor the successful realization of the business model designed by its incubated (Hackett \& Dilts, 2004). Literature shows that the incubation process results in companies with a unique context (Lopes et al., 2018), which stimulates further investigations.

The herein study contributes to the literature by identifying associations of organizational characteristics, such as the interactive use and diagnosis of the MCS and slack time with processes innovation in organizations with contemporary configuration. The results can also direct such companies to the achievement of greater efficiency in the search for innovation. This study is appropriate in such organizations, as incubated companies are originated from an innovative idea and a link with a business incubator, and they seek to develop and subsequently sustain their business. Therefore, they will be able to use the results of this study to review their innovative orientation and the use of the MCS more in line with their strategies and to review organizational slack policies. 


\section{THEORETICAL BACKGROUND AND HYPOTHESES}

\subsection{MCS use and slack time}

The design and use of the MCS affect organizational performance (Guenther \& Heinicke, 2019). The design refers to its characteristics, while the use refers to the purpose and intensity of the application in organizations. Simons (1995) developed a model for the conception of the MCS focused on the implementation of organizational strategy. This taxonomy, called Levers of Control, proposes a balance in the use of four levers: belief systems, boundary systems, diagnostic control systems, and interactive control systems (Simons, 1995).

Belief systems are intended to convey the values set by the organization, guiding and directing the pursuit of opportunities, while boundary systems point limits and rules to managers as a way to minimize existing risks, so as not to lose focus on organizational goals (Simons, 1995). Diagnostic control systems are characterized as a way of monitoring based on variance analysis, useful for identifying organizational deviations, and lead to short-term goals and focus (Simons, 1995). Interactive control systems are characterized by contact and interaction management, whose interactive approach encourages the use of emerging strategies and instigates experimentation (Simons, 1995).

Diagnostic and interactive control systems represent two formalizations of the use of the MCS and are characterized by being counterbalanced in organizations, in which the interactive exerts positive force and the diagnostic negative. Thus, it is postulated that both levers fulfill the purpose of investigating the effects of different forms of using the MCS, according to the assumptions presented by Simons (1990). These two levers substantiated the research conducted by Abernethy and Brownell (1999), who investigated the interactive and diagnostic use of the budgeting system, and the results revealed that the managers' interactive use of budget leads to the promotion of learning and offers the possibility of adaptation that the contexts of strategic change require. Overall, the benefits were greater with the interactive use in the context of high formalization of systems. These results prompt research with associations of other variables.

Organizational slack has proved to be an important variable in organizational studies, as the literature on this construct shows that slack has several purposes, such as facilitating strategic behaviors (Bourgeois III, 1981). The slack can be represented according to its nature (Lawson, 2001), which 
motivated a series of studies that analyzed the slack of different organizational resources, especially financial, and correlated with the budgeting. Mallidou et al. (2011) state that slack is a multidimensional construct that can be operationalized not only in financial terms but also as slack of human, physical and time resources.

According to Mallidou et al. (2011), slack time in the organizational context refers to the extra time for activities development, learning and meeting deadlines. The presence of slack time can be identified in companies from the availability of extra time to perform tasks, discussions, organizational learning, or even goals and deadlines (Beck \& Beuren, 2015). Lawson (2001) warns that the time considered necessary for the development of tasks, learning and meeting deadlines needs to be established in the organizations.

Sharfman and Dean Jr. (1997) identified that flexibility in organizations is positively related to organizational slack and that higher levels of slack lead to new ideas and a context with greater communication. Among the motivations for creating slack time, Schoute and Wiersma (2011) identified that it is less frequent when intended for coordination and evaluation/compensation, and more used for planning and organizational communication. These characteristics are contextual, with the predominant use of interactive MCS, characterized by flexibility and communication, with high levels of organizational slack. Zhor (2018) found out that interactive MCS are aligned with innovation, and that control aids in determining the appropriate level of slack.

Thus, it is postulated that the diagnostic use, characterized by monitoring, evaluation and greater control, favors the creation of slack time, while the interactive use, characterized by communication, participation in the definition of objectives and goals, decreases the propensity of its creation. In this sense, the first hypothesis of the research was formulated:

- $\mathrm{H}_{1 \mathrm{a}}$ : There is a positive influence of the interactive use of the MCS on slack time.

- $\mathrm{H}_{1 \mathrm{~b}}$ : There is a negative influence of the diagnostic use of the MCS on slack time.

\subsection{Slack time and processes innovation}

Bourgeois III (1981), a long time ago, pointed out that the efficiency of resources allocation does not guarantee organizational success. Slack time can pose risks to the organization, as it can be used to focus on activities 
that require it, such as innovation (Tan \& Peng, 2003). While on the one hand, slack favors innovation, on the other hand, it is seen as waste resources that do not add to the results (Lawson, 2001; Tan \& Peng, 2003). There are mixed results in the literature, with empirical evidence of associations between different types of slack and innovations, causing divergent effects (Marlin \& Geiger, 2015).

According to Tan (2003), organizational slack provides managers with a versatility that can be used to develop and execute strategies. However, there are views that relate slack time to dysfunctional behaviors, such as generating unnecessary expenses for the organization (Tan \& Peng, 2003). Nohria and Gulati (1996) add that it is not good for the organization not to have slack time, or have too much slack time, since, without slack time, experimentation and new ideas may not be sustained, just as too much slack time makes it difficult to maintain the discipline and select which projects to support.

Organizational slack is associated with innovation in a way that higher slack levels enable higher levels of generating new knowledge and the emergence of new ideas (Sharfman \& Dean Jr., 1997). Even in the face of uncertainties, organizational slack allows the execution of new products/processes (Beck \& Beuren, 2015). Slack time is essential for innovation. It is an essential resource for business development, not a waste of time (Lawson, 2001). The herein study presupposes slack time as a catalyst for processes innovation, reflected in the second research hypothesis:

- $\mathrm{H}_{2:}$ There is a positive influence of slack time on processes innovation.

\subsection{Interactive and diagnostic use of MCS and process innovation}

Innovation is related to opportunities, experimentation, uncertain outcomes and predisposition to risk (Davila, Foster, \& Oyon, 2009). Processes innovation, according to the Organization for Economic Co-operation and Development (OECD, 2005), is a type of technological innovation, linked to the implementation of new or significantly improved methods in the production or distribution process innovations that include changes in equipment, software or techniques, aimed at reducing costs and improving efficiency and quality. Processes innovation regards the implementation of a new strategy (Ashok, Narula, \& Martinez-Noya, 2016).

Studies have shown divergent results on the association between MCS and innovation (Bisbe \& Otley, 2004; Lopes et al., 2018). Despite the apparent 
conflict between MCS and the importance of creativity and innovation, these systems are present and relevant to the processes of creativity and innovation (Davila et al., 2009). Lopes et al. (2018) found out that the different ways MCS are used in incubated companies have different implications for innovation, but the main evidence is of the associations with interactive control systems.

Interactive control system offers greater support to the implementation of strategies in competitive and rapidly changing environments (Simons, 1995). Widener (2007) argues that interactive control systems are mainly associated with learning organizations. According to Bisbe and Otley (2004), the model proposed by Simons highlights the relevance of the interactive use to leverage innovation. Malagueño and Bisbe (2010) presented results suggesting that the interactive use of MCS is important for the development of innovation practices.

Simons (1995) argues that the diagnostic use restricts innovation because it focuses on monitoring and on achieving organizational goals, while the interactive use promotes the emergence of creative ideas as a consequence of interaction and learning. Cruz, Frezatti, and Bido (2015) did not confirm an association between the use of the diagnostic control system and technological innovation of products and processes, but found a positive association between the interactive use and such innovations. More flexible, the interactive use is considered more appropriate than the diagnostic use to evaluate opportunities and strategies consistent with processes innovation, which tends to be more restrictive and mechanistic (Simons, 1995; Demartini \& Mella, 2014). In this perspective, the third hypothesis was formulated:

- $\mathrm{H}_{3 \mathrm{a}}$ : There is a positive influence of the interactive use of the MCS on processes innovation.

- $\mathrm{H}_{3 \mathrm{~b}}$ : There is a negative influence of the diagnostic use of the MCS on processes innovation.

\subsection{Mediation of slack time in the relationship between the use of MCS and processes innovation}

According to Zhor (2018), to get the most benefit from slack, top management should use the interactive control system. Organizational slack is more likely to be created when the organization provides a less formalized environment, as in the case of the interactive use of the MCS, whereas the diagnostic use may inhibit slack creation by its more efficiency-oriented 
strategy. Based on the purposes of the diagnostic and interactive use of the MCS, outlined by Simons (1995), there is an alignment between the view of organizational slack as a dysfunctionality when the diagnostic use of the MCS is applied, in which all excess is seen as a deviation that should be noted. On the other hand, the interactive use of the MCS offers a greater possibility of creating slack time by stimulating interactions and learning.

There are positive and negative aspects of slack and MCS (Simons, 1995; Tan, 2003; Zhor, 2018), as well as their relationship with innovation (Sharfman \& Dean Jr., 1997; Beck \& Beuren, 2015; Marlin \& Geiger, 2015). Since the interactive use of MCS positively influences slack, managers can regulate slack resources to build a configuration that facilitates the innovation process (Zhor, 2018). The MCS are able to provide managers with a more effective strategy on how to employ organizational slack (Zhor, 2018); which has been shown to facilitate innovation (Sharfman \& Dean Jr., 1997).

The herein study proposes to verify the mediating role of slack time in the relationship between MCS and innovation. This proposition stems from the evidence that the use of MCS influences organizational slack (Simons, 1995; Tan, 2003; Zhor, 2018) and that the configuration of the slack positively influences process innovation in innovative firms (Sharfman \& Dean Jr., 1997; Beck \& Beuren, 2015). Following the line of studies that characterize slack as a promoter of innovation (Sharfman \& Dean Jr., 1997; Beck \& Beuren, 2015), it is assumed an active role of slack in the relationship between MCS and innovation, and it is postulated that the influence of MCS on innovation is due to slack time. Thus, the fourth research hypothesis was formulated:

- $\mathrm{H}_{4}$ : There is an indirect influence of the interactive use and diagnosis of the MCS on processes innovation, mediated by slack time.

With the formulation of the hypotheses, from the theoretical-empirical evidence presented in the literature, the theoretical model of the research is conceived, as illustrated in Figure 2.4.1. 


\section{(Figure 2.4.1)}

THEORETICAL MODEL OF THE RESEARCH

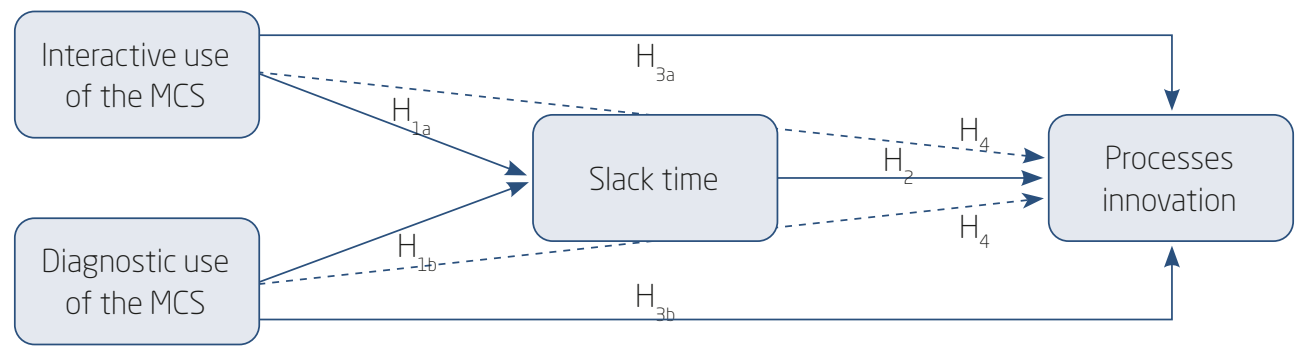

Intermittent lines refer to the mediation relationship (indirect effect).

Source: Elaborated by the authors.

\section{METHODOLOGICAL PROCEDURES}

\subsection{Population and sample}

A survey was conducted in companies incubated in incubators associated with the Associação Nacional de Entidades Promotoras de Empreendimentos Inovadores (Association of Promoters of Innovative Enterprises - Anprotec). The mapping of the incubated companies listed on the websites of incubators associated with Anprotec, in December 2017, resulted in a total of 1,890 companies. The companies' conception goes through some incubation stages, comprising: pre-incubation $(8.6 \%)$, more focused on planning; incubation (37.1\%); and graduation (54.3\%), stage after incubation.

For data collection, the name of each incubated company was searched in the professional network LinkedIn, identifying 1,121 managers in strategic positions linked to them. The submission rate was of three respondents per company, and preference was given to contact positions of higher hierarchical levels. A total of 499 managers expressed interest in participating in the study. From the acceptance of the LinkedIn invitation, the link to the questionnaire available at the QuestionPro platform was sent from December 2017 to March 2018. The procedures adopted resulted in 106 valid answers. The statistical power of the sample size was calculated by using the $\mathrm{G}^{*}$ Power software, considering effect (mean) of 0.15 , significance level of $\alpha=0.05$ and sample power of $1-\beta=0.8$ (Faul, Erdfelder, Buchner, \& Lang, 2009).

In the sample, $85 \%$ of the managers are male. The average age was 41 and $81 \%$ of the managers are between 19 and 40 years old. About the 
involvement with the company, $12 \%$ indicated they are owners; $65 \%$ partners; and $23 \%$ are employees. As for positions, $59 \%$ are directors; $20 \%$ managers/administrators; $5 \%$ analysts; and $16 \%$ hold other positions. Regarding the year of foundation of the company, $8 \%$ indicated that it was founded less than two years ago; $37 \%$ between two and five years; $30 \%$ between five and ten years; and $26 \%$ over ten years. There is a wide range, from companies that operate from half a year to 30 years in the market.

\subsection{Constructs and variables}

The constructs and variables of this research are presented in Figure 3.2.1.

(Figure 3.2.1)

CONSTRUCTS AND VARIABLES

\begin{tabular}{|c|c|c|c|}
\hline Constructs & Variables & Definition & Authors \\
\hline \multirow[t]{2}{*}{$\begin{array}{l}\text { Use of the MCS } \\
\text { (ten assertions) }\end{array}$} & $\begin{array}{l}\text { Interactive use } \\
\alpha=0.942\end{array}$ & $\begin{array}{l}\text { Use of MCS aligned with the organization's strategy } \\
\text { leads to the congruence of strategic objectives } \\
\text { through contact and interaction. }\end{array}$ & \multirow{2}{*}{$\begin{array}{l}\text { Abernethy and } \\
\text { Brownell (1999) } \\
\text { and Naranjo-Gil e } \\
\text { Hartmann (2006). }\end{array}$} \\
\hline & $\begin{array}{l}\text { Diagnostic use } \\
\alpha=0.929\end{array}$ & $\begin{array}{l}\text { Use of MCS aims at monitoring organizational } \\
\text { results, ensuring compliance with objectives with } \\
\text { minor deviations and it has a low level of flexibility. }\end{array}$ & \\
\hline $\begin{array}{l}\text { Slack time } \\
\text { (four assertions) }\end{array}$ & $\begin{array}{l}\text { Slack time } \\
\alpha=0.894\end{array}$ & $\begin{array}{l}\text { Excessive time during the development of routine } \\
\text { activities, enabling greater organizational } \\
\text { interaction and development of extra actions. }\end{array}$ & $\begin{array}{l}\text { Mallidou et al. } \\
\text { (2011) }\end{array}$ \\
\hline $\begin{array}{l}\text { Processes } \\
\text { innovation (five } \\
\text { assertions) }\end{array}$ & $\begin{array}{l}\text { Processes } \\
\text { innovation } \\
\alpha=0.917\end{array}$ & $\begin{array}{l}\text { Intensity and breadth of the results of processes } \\
\text { innovation in the organization, how much internal } \\
\text { innovation has been accomplished with different } \\
\text { purposes. }\end{array}$ & $\begin{array}{l}\text { Ashok et al. } \\
\text { (2016) }\end{array}$ \\
\hline
\end{tabular}

Source: Elaborated by the authors.

The research instrument encompassed the variables of the constructs, measured by assertions in a Likert-type scale anchored in seven points, adapted from previous studies. The use of the MCS was measured by the research instrument of Naranjo-Gil and Hartmann (2006), elaborated based on the study conducted by Abernethy and Brownell (1999), which considers the possibilities of using the MCS, with interactive or diagnostic emphasis, two of the four levers of control of Simons' framework (1995). The instrument with ten assertions about characteristics of the use of MCS shows the degree of agreement regarding the use of control for such purposes. Explora- 
tory factor analysis (EFA) grouped such purposes between interactive and diagnostic use, according to Naranjo-Gil and Hartmann (2006). The model demonstrated acceptable adequacy level $(\mathrm{KMO}>0.7=0.856)$ and excellent internal consistency $(\alpha=>0.91)$.

Slack time has been investigated in routine tasks, in which the presence of slack time indicates that the time spent on their activities is not fully predefined and rigid. The instrument was adapted from the study conducted by Mallidou et al. (2011), originally applied to healthcare employees. It questioned the extent to which some aspects represent the organization's routine, measured by the degree of agreement regarding: "in our organization, we have the time available to do something extra for our clients"; "to talk with colleagues about our clients"; "to look for something that interests us in extra materials (e.g., in newspapers, on the internet)"; "to talk with colleagues about any news or innovation in the area". The unidimensionality of the construct was confirmed by the EFA, with model adequacy (KMO = $0.791)$ and good internal consistency of the instrument $(\alpha=>0.81)$.

Process innovation was measured by the organization's innovative strategy focused on its internal processes. To this end, we used the metric of Ashok et al. (2016), which assesses the degree of agreement regarding the results of processes innovation, based on OECD (2005) definitions, as follows: "our organization has developed new or considerably improved processes"; "which increased the profit margin on sales"; "which led to the conquest of new customers"; "which resulted in competitive advantage"; "which has increased the ability to meet the customers' needs". The unidimensionality of the construct was attested by EFA, with adequacy of the model (KMO = $0.882)$, and excellent internal consistency $(\alpha=>0.91)$.

\subsection{Data analysis procedures}

In the data analysis, we used techniques of descriptive analysis, EFA and Structural Equation Modeling (SEM), estimated from the Partial Least Squares (PLS) technique. EFA precedes SEM, which verifies the theoretical groupings that the constructs form, measured by multiple scales. In the factor analysis procedures, all assertions presented reliability indices, internal consistency and satisfactory sampling adequacy (Fávero \& Belfiore, 2017).

The EFA was calculated using varimax rotation and Kaiser normalization and did not imply exclusion of assertions from the study (Fávero \& Belfiore, 2016). The factor analysis created four main components, one for each study variable, with the first component showing only $39 \%$ of the total variance, 
below the common threshold of 50\%, according to Harman's single factor test (Podsakoff, MacKenzie, Lee, \& Podsakoff, 2003). The test suggests that the data are not affected by a common method variance higher than the accepted threshold in the literature, even if all variables were reported by the same respondent at the same time.

As the sample is not equivalent to the population and the response rate was low $(<10 \%)$, there were possible distortions in the sample by the nonresponse bias test. By testing for differences in responses from the first and last $25 \%$ of the respondents, it is interpreted that the late ones are similar to those who did not participate in the survey (Wåhlberg \& Poom, 2015). The t-test was applied to independent samples and the responses of each statement were compared between the two groups. The results did not indicate significant differences between them, indicating acceptable indices of non-response bias, calculated by the firsts-lasts method at a significance level of $5 \%$.

To analyze the proposed relationships, we used the SEM estimated by the PLS. Direct relationships were analyzed by path coefficients between variables, and indirect relationships by total indirect coefficients (Hair Jr., Hult, Ringle, \& Sarstedt, 2016). To confirm the mediating effect, we followed the four steps proposed by Baron and Kenny (1986): 1. the independent variable affects the mediator; 2 . the independent variable affects the dependent; 3. the mediating variable affects the dependent; and 4. the effect of the independent variable on the dependent one weakens with the addition of the mediator variable.

\section{DESCRIPTION AND ANALYSIS OF THW RESULTS}

\subsection{Factorial analysis of the assertions on the use of the MCS}

Initially, we analyzed the existence of two forms of use of the MCS (interactive and diagnostic), as proposed in the research instrument of Naranjo-Gil and Hartmann (2006). EFA was calculated with varimax rotation and groupings based on eigenvalue and Kaiser's normalization (Fávero $\&$ Belfiore, 2017). Two theoretical groupings are verified, which implied the minimization of the number of variables with high loads in the same factor, leading to the reduction of ten variables in two dimensions. The results of the EFA are presented in Figure 4.1.1. 


\section{(Figure 4.1.1)}

FACTORIAL ANALYSIS OF THE ASSERTIONS ON THE USE OF THE MCS

\begin{tabular}{|c|c|c|}
\hline Use of the MCS & $\begin{array}{c}\text { Factor } 1 \\
\text { Interactive use }\end{array}$ & $\begin{array}{c}\text { Factor } 2 \\
\text { Diagnostic use }\end{array}$ \\
\hline MCS 1 : Defines and negotiates goals and targets & 0.815 & 0.219 \\
\hline MCS $_{2}$ : Discusses data assumptions and action plans & 0.810 & 0.328 \\
\hline 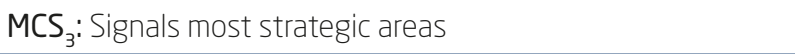 & 0.780 & 0.308 \\
\hline MCS $_{4}$ : Challenges new ideas and ways to do tasks & 0.847 & 0.109 \\
\hline MCS : Keeps up with the exceptions and deviations & 0.793 & 0.290 \\
\hline MCS: Pays constant attention to subordinates & 0.304 & 0.873 \\
\hline MCS : Strictly examines and controls subordinates & 0.237 & 0.902 \\
\hline MCS: Tracks preset plans and goals & 0.666 & 0.333 \\
\hline MCS: Aligns performance measures with strategic objectives & 0.735 & 0.375 \\
\hline MCS $_{10}$ : Serves as a learning tool & 0.728 & 0.216 \\
\hline Eigenvalue & 6.111 & 1.044 \\
\hline Variance extracted (\%) & 61.11 & 10.44 \\
\hline Cronbach's Alpha & 0.942 & 0.929 \\
\hline
\end{tabular}

$N=106$. Kaiser-Meyer-Olkin (KMO) = 0.856 .

\section{Source: Elaborated by the authors}

The construct use of the MCS formed two theoretical groupings (dimensions), predominantly of interactive use, having eight assertions, while diagnostic use had two assertions. None of questionnaire's assertions obtained factor loadings below the acceptable parameters for the sample size $(>0.550)$. The overall adequacy of factor extraction, measured by the KMO, ensures the existence of a common factor and reveals the adequacy of the sampling. As for the magnitude of the measurement, Cronbach's alpha shows excellent internal consistency $(>0.91)$. These criteria allowed us to proceed with the analysis of the measurement model of the use of the MCS in two variables, interactive use and diagnostic use, which represent two levers of Simons' model (1995).

\subsection{Measurement model}

In SEM, it is necessary to certify the validity (convergent and discriminant) and the reliability (internal and composite) of the variables, inter- 
preted based on criteria disseminated in the literature and presented by Hair Jr. et al. (2016). Figure 4.2.1 presents the results of these tests.

(Figure 4.2.1)

MEASUREMENT MODEL

\begin{tabular}{|c|c|c|c|c|}
\hline Indicators Latent variables & $\begin{array}{l}\text { Interactive } \\
\text { use MCS }\end{array}$ & $\begin{array}{l}\text { Diagnostic } \\
\text { use MCS }\end{array}$ & $\begin{array}{l}\text { Slack } \\
\text { time }\end{array}$ & $\begin{array}{l}\text { Processes } \\
\text { innovation }\end{array}$ \\
\hline Interactive use MCS & 0.818 & & & \\
\hline Diagnostic use MCS & 0.590 & 0.931 & & \\
\hline Slack time & 0.365 & 0.074 & 0.823 & \\
\hline Processes innovation & 0.423 & 0.331 & 0.035 & 0.831 \\
\hline Mean & 4.92 & 3.94 & 5.26 & 5.16 \\
\hline Standard Deviation & 1.27 & 1.48 & 1.32 & 1.33 \\
\hline Coefficient of variation (\%) & $25.81 \%$ & $37.56 \%$ & $25.10 \%$ & $25.78 \%$ \\
\hline Mode & 5 & 5 & 7 & 6 \\
\hline Average Variance Extracted (AVE) $>0.50$ & 0.669 & 0.867 & 0.678 & 0.690 \\
\hline Cronbach's Alpha >0.70 & 0.930 & 0.852 & 0.843 & 0.886 \\
\hline Composite Reliability $(\mathrm{CR})>0.70$ & 0.942 & 0.929 & 0.894 & 0.917 \\
\hline
\end{tabular}

Diagonal elements represent the square roots of the extracted mean variance and off-diagonal elements represent the correlations between the latent variables. $\mathrm{N}=106$.

\section{Source: Elaborated by the authors.}

In the measurement model, it begins with the verification of the loadings of each assertion that makes up the four formative constructs. Loads higher than 0.70 are recommended, verified in 17 assertions, except in two on processes innovation, higher than 0.65 , whose exclusion did not cause an increase in the average variance extracted (AVE) and in composite reliability (CR), which justifies keeping all assertions in the study, according to Hair Jr. et al. (2016).

The internal consistency of the variables (Cronbach's alpha) and the CR of all variables are considerably higher than the limits established in the literature $(>0.70)$, indicating that the model is adequate, in terms of reliability. The validity and reliability of the variables measured based on the extracted mean variance were also attested, with AVE coefficients greater than 0.50 , indicating that, on average, the variable explains more than half of the variance of its indicators (Hair Jr. et al., 2016). 
Discriminant validity was examined through cross-load and Fornell and Larcker (1981) criteria. The first one showed the absence of a high correlation between the assertions, and the second one showed that the square root values of the average variance extracted from each variable are higher than the correlations between the variables, attesting that each variable is individually distinct from the others (Hair Jr. et al., 2016). Variance Inflation Factors (VIF) indicate the absence of multicollinearity between variables (VIF < 5), according to Hair Jr. et al. (2016). The results of the measurement model indicate that all variables are characterized by sufficient levels of reliability and validity, which attests their suitability to proceed with the analysis of structural relationships.

The descriptive statistics of the variables show that the average answers to the statements that formed the interactive use of the MCS was 4.92, indicating moderate to high use, while the diagnostic use showed values in the first half of the scale, indicating lower intensity, when adopted. Slack time at work was high, with mode 7 , so, in most cases, employees have high levels of slack time in their activities, which may result from the positions of the respondents, the majority being owners or partners of the company. Process innovation indicates that the sample companies have moderate to high intensity of processes innovations, mean of 5.16 on a seven-point Likert scale.

\subsection{Structural model and hypothesis test}

In order to test the structural model of the exploratory paths, we performed the bootstrapping of the model with five thousand re-samples and bias-corrected confidence interval to obtain the structural coefficients and their significance in each relationship. The structural model was evaluated based on the Pearson's coefficient of determination $\left(R^{2}\right)$, predictive relevance $\left(Q^{2}\right)$, and effect size or Cohen's indicator $\left(\mathrm{f}^{2}\right)$ (Hair Jr. et al., 2016). Results are shown in Figure 4.3.1.

\section{(Figure 4.3.1)}

RESULTS OF THE STRUCTURAL MODEL: HYPOTHESIS TEST

\begin{tabular}{ccccccc}
\hline Hypothesis & $\begin{array}{c}\text { Structural } \\
\text { coefficient }\end{array}$ & $\begin{array}{c}\text { Standard } \\
\text { error }\end{array}$ & $\boldsymbol{t}$-value & $\boldsymbol{p}$-value & Decision \\
\hline $\mathrm{H}_{1 \mathrm{a}}$ Interactive use $\rightarrow$ slack time & 0.493 & 0.100 & 4.942 & 0.000 & Accepted \\
\hline $\mathrm{H}_{1 \mathrm{~b}}$ Diagnostic use $\rightarrow$ slack time & -0.217 & 0.113 & 1.919 & 0.058 & Accepted \\
\hline
\end{tabular}




\section{(Figure 4.3.1 (conclusion))}

RESULTS OF THE STRUCTURAL MODEL: HYPOTHESIS TEST

\begin{tabular}{lcccccc}
\hline Hypothesis & $\begin{array}{c}\text { Structural } \\
\text { coefficient }\end{array}$ & $\begin{array}{c}\text { Standard } \\
\text { error }\end{array}$ & $\begin{array}{l}\boldsymbol{t} \text {-value } \\
\text { p-value }\end{array}$ & Decision \\
\hline $\mathrm{H}_{2}$ Slack time $\rightarrow$ processes innovation & -0.122 & 0.103 & 1.183 & 0.240 & Rejected \\
\hline $\mathrm{H}_{3 \mathrm{a}}$ Interactive use $\rightarrow$ processes innovation & 0.409 & 0.117 & 3.499 & 0.001 & Accepted \\
\hline $\mathrm{H}_{3 \mathrm{~b}}$ Diagnostic use $\rightarrow$ processes innovation & 0.099 & 0.109 & 0.906 & 0.367 & Accepted \\
\hline
\end{tabular}

$N=106$. Structural model evaluation $\left(R^{2}\right)$ : slack time 0.164; processes innovation 0.201.

Predictive relevance $\left(Q^{2}\right)$ : time lag 0.081; processes innovation 0.116.

Effect size $\left(f^{2}\right)$ : interactive use 0.189; diagnostic use 0.037; slack time 0.016 .

\section{Source: Elaborated by the authors.}

The analysis of structural coefficients indicates significant and positive effect of the interactive use of the MCS on slack time $(0.493, p<0.001)$, and significant and negative effect of the diagnostic use of the MCS on slack time $(-0.217, \mathrm{p}<0.10)$, which confirms the hypothesis $\mathrm{H}_{1}$, that there is a positive influence of interactive use on slack $\left(\mathrm{H}_{1 \mathrm{a}}\right)$ and negative influence of diagnostic use on slack $\left(\mathrm{H}_{1 \mathrm{~b}}\right)$. The association between slack time and processes innovation was not statistically significant $(\mathrm{p}>0.10)$ nor it had a positive coefficient, leading to the rejection of the hypothesis $\mathrm{H}_{2}$. It is observed that the interactive use of the MCS is positively associated with processes innovation $(0.409, \mathrm{p}<0.001)$, allowing to accept $\mathrm{H}_{3 \mathrm{a}}$. However, the diagnostic use of the MCS did not confirm negative association with innovation and did not present statistical significance $(\mathrm{p}>0.10)$, which leads to the rejection of the hypothesis $\mathrm{H}_{3 \mathrm{~b}}$.

Hypothesis $\mathrm{H}_{4}$ sought to verify the mediating effect of slack time on the relationship between the use of the MCS and processes innovation. The steps recommended by Baron and Kenny (1986) cannot be confirmed to attest the mediating effect, since, in the diagnostic use, two of the three direct relationships (steps 1 and 2) were not confirmed, and, in the interactive use, the influence of the dependent mediating variable (step 3), which does not allow the analysis of the mediating effect (step 4). Thus, H4 is rejected, since it cannot be confirmed that the influence of the use of the MCS (interactive or diagnostic) on processes innovation occurs through slack time, since the slack time and the diagnostic use of the MCS are not significantly related to innovation.

To attest to the validation of the structural model, Pearson's coefficient of determination $\left(\mathrm{R}^{2}\right)$ evaluates the proportion of variance of variables that 
is explained by the structural model. Slack time is explained by the model at $16.4 \%$, and innovation at $20.1 \%$, coefficients of determination that indicate average predictive power (Hair Jr. et al., 2016). The effect size ( $\left.f^{2}\right)$ or Cohen's indicator (1988), assesses how useful each variable is for the adjustment of the model. The interactive use had a medium effect $\left(\mathrm{f}^{2}>0.15\right)$, while the diagnostic and slack time had a small effect (Hair Jr. et al., 2016). $Q^{2}$ values confirm the accuracy of the model $\left(Q^{2}>0\right)$ (Hair Jr. et al., 2016).

\subsection{Discussion of the results}

The herein study analyzed the relationship between the interactive and the diagnostic use of the MCS and processes innovation, mediated by slack time. The results are shown in Figure 4.4.1.

(Figure 4.4.1)

RESULTS OF THE STRUCTURAL MODEL

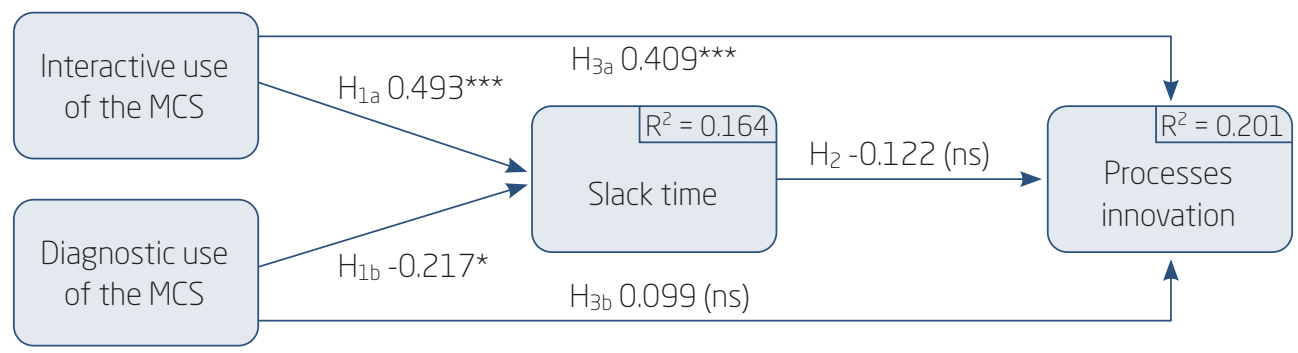

Values are the structural coefficients of each path obtained through bootstrapping in PLS-SEM.

Significant at the level of ${ }^{* \star *} p<0.001$; ${ }^{*} p<0.10$; ns: not significant. $N=106$.

Source: Elaborated by the authors.

The results show that the interactive use of the MCS predominates in the companies surveyed since among the ten statements presented in the research instrument, eight were pointed out as interactive use. This suggests that the managers of these companies operationalize the objectives through a more flexible and dynamic management model, characterized by interaction and flexibility in the operationalization of their strategies.

$\mathrm{H}_{1 \mathrm{a}}$ predicted a positive relationship of the interactive use of the MCS over time, which was accepted at a significance level of 1\%. Zhor (2018) points out that the ideal level of clearance can be achieved through the interactive use of the MCS. Here, the interactive use of the MCS is associated with higher levels of slack time in routine business activities. Although the slack time in the work of the employees of the organization has been 
questioned, the high levels of slack time may result from the positions of the respondents, the majority indicated that they are owners or partners of the company, therefore, they have autonomy to create high levels of slack time. Thus, a positive alignment was found between the use of the MCS with greater interaction and focused on learning with the creation of slack time, which favors creativity and experimentation.

$\mathrm{H}_{1 \mathrm{~b}}$ predicted a negative relationship between the diagnostic use of the MCS over time, which was confirmed at a significance level of $10 \%$. Therefore, the more mechanistic the use of the MCS, the less will the slack time be in these companies. This is in line with the study conducted by Simons (1995), in which the diagnostic use of the MCS, aimed at meeting goals and identifying organizational deviations (e.g., slack time understood as waste/ dysfunctionality), leads to the creation of lower levels of slack time, which allows negative and positive interpretation of the consequences of the diagnostic use, depending on the implications of the slack time for the organization. It is inferred that the diagnostic use of the MCS, even in innovative companies, fulfills its role of ensuring the monitoring and execution of tasks with lower levels of deviations compared to the interactive use, by restricting the possibility of creating slack time at work.

From the results pointed out in $\mathrm{H}_{1}$, it was observed that the interactive use of the MCS is associated with higher levels of slack time at work, while the diagnostic use of the MCS restricts it. These formalizations direct organizations to the execution of organizational objectives for different purposes. By demonstrating a relationship only between the interactive use and the processes innovation, while the diagnostic use inhibits the creation of slack time, which was not proven to be beneficial to the organization, the complementary roles of the control levers of Simons' model (1995) are evidenced, in which the diagnostic use exerts a negative force, and the interactive use, a positive one.

$\mathrm{H}_{2}$, which predicted a positive relationship between slack time and processes innovation, was not confirmed. Even without statistical significance, it presented negative coefficients, which, if confirmed, would prove a dysfunctional role of slack time in processes innovation. This result is not in line with that of Sharfman and Dean Jr. (1997), which may be due to the specificity of the sample and the type of slack and innovation investigated. Another possibility is that processes innovation tends not to be implemented quickly, i.e., it is unlikely to result immediately after creating slack in the organization. Schoute and Wiersma (2011) warn that slack time needs a long-term view. The indicated level of slack (mode 7 ) is superior to any possibility of organizational benefit. Nohria and Gulati (1996) add that high 
levels of slack do not bring so many benefits to consider them an efficient resource outlay.

In the study, positive relationships between slack time and process innovation were not confirmed. One of the possible reasons may be the characteristics of the incubated companies, with a strong presence of owners, who have the autonomy to create slack time. However, several factors influence the creation of different types of slack. A high level of slack time in activities may indicate dysfunctionality under the lens of processes innovation, but no statistical significance was found to support negative influence, which indicates that the slack did not promote or inhibit innovation.

$\mathrm{H}_{3 \mathrm{a}}$, that predicted a positive relationship between the interactive use of the MCS and processes innovation, was accepted, which is in line with the findings of Cruz et al. (2015), Demartini and Mella (2014) and Frezatti et al. (2017) and Simons (1995). It is also in line with Widener's findings (2007) that interactive controls are often linked to more learning-driven companies, leveraging innovation. According to Simons (2000), processes innovation depends on how control is used in the organization since interactive control is more flexible and dynamic to deal with uncertainties.

$\mathrm{H}_{3 \mathrm{~b}}$, which predicted a negative relationship between the diagnostic use of the MCS and processes innovation, was not statistically significant. Such result was also observed in the study conducted by Cruz et al. (2015) regarding technological innovation. This suggests that, when managers use the MCS with diagnostic emphasis, their focus is not on creating a context that fosters organizational outcomes, such as innovation, but on monitoring and meeting pre-set goals. Thus, they do not end up promoting innovation, which is not necessarily bad, because in some organizational activities only the operationalization of the strategy is required.

In short, interactive control provides a less formalized context and favors communication and learning, and positively influences slack time and processes innovation in incubated companies. The diagnostic use, that focuses on aligning employees' behavior with the organizational objectives, implementing strategies and correcting deviations, has negatively influenced the creation of slack time, seen as a misuse of resources (planned versus accomplished), and turned out not to inhibit innovation in companies. This empirical evidence suggests that the implementation of different strategies requires different ways of using the MCS. It is postulated that interactive use should prevail when the purpose is to promote processes innovation, while the diagnostic use highlights its relevance in ensuring efficient resource allocation.

The hypothesis of mediation $\left(\mathrm{H}_{4}\right)$, which predicted the relationship between interactive use and diagnosis of MCS with time-delayed process 
innovation, was rejected for both forms of use, as the significance of all direct relationships was not confirmed. Therefore, slack cannot be considered to explain the relationship between the MCS and innovation, as slack has not confirmed association with processes innovation. Thus, it cannot be assumed that the direct effect of the MCS on innovation is explained by slack time, other slacks of resources may be more closely linked to innovation, or whose link is more perceived (less subjective) and occurs immediately.

The empirical evidence presented has theoretical implications, since, despite the active role of control systems in the slack of organizational resources, few studies relate slack time to the use of the MCS to explain individual behaviors, which leads to organizational results. The study shows evidence to the contrasting findings of the literature on the interactions of the MCS with slack time and processes innovation and the identification of a dual role of control systems in this context, and also shows that slack time is not necessarily associated with higher levels of innovation. Thus, the logic that organizational slack is a necessary resource for activities that require creativity and at what levels such resources can be effectively used to promote organizational results rather than wasting resources are questioned.

As practical implications, it is emphasized the possibility of the use of the MCS to act as a guide for organizational objectives and for monitoring the processes innovation. The interactive use of the MCS was very present in these organizations, influencing the promotion of innovation. It is also stressed the relevance of companies reviewing their policies around slack time, which should be planned and implemented at a level considered ideal to the organizational context, according to the need for slack time the tasks require. It is inferred that the average levels of slack time established in the investigated companies are higher than what may be considered efficient for processes innovation, but it may be resulting in other organizational benefits, which are encouraged to be investigated.

However, it is noteworthy that the cross-sectional nature of the study limits some statistical inferences and even the behavior of this evidence over time. Future research may investigate the interaction of the variables presented in this study with other time frames and in other contexts. In this study, we sought to foster discussion about potential factors that may explain the influence of the MCS on processes innovation, which was not verified by the slack time. Thus, future studies are encouraged to seek evidence to attest to the mediating effect of other variables on the relationship between the MCS and innovation. Other studies may focus on the interactive and the diagnostic use of specific MCS, such as the budget system or the 
performance measurement system. The enabling or coercive use of the MCS is another suggestion for investigating the effects on slack creation and on different forms of innovation (e.g., strategic technological and market innovation).

\section{CONCLUSIONS}

This study analyzed the influence of the interactive and the diagnostic use of the MCS and slack time on processes innovation in incubated companies. Although the interactive use of the MCS by managers prevailed for the implementation of the organizational strategy, it was observed that the interactive use and the diagnostic use act in a complementary way and pose different implications to the organizations, which justifies and encourages the literature debate on the use of MCS to implement innovative strategies. This points to the dual role of the control levers of Simons' model (1995), which act with different forces, but in a complementary way, aiming at the congruence of the organizational objectives.

Although no direct influence of slack time on process innovation in incubated companies has been confirmed, slack time is considered essential in creative processes when it happens at an appropriate level. As noted by Nohria and Gulatti (1996) and Agrawal et al. (2018), it is inferred that the effectiveness of the slack of resources is an inverted U-shaped curve, which, to some extent, leads to benefits (e.g. creativity and quality of work), since the slack levels in the investigated companies are high, but this did not imply higher levels of processes innovation. These findings alert to the need for companies to adopt adequate levels of organizational slack, so as not to waste resources, which characterizes a dysfunctional role of slack time in the investigated companies, contrary to much of the literature on the subject.

\section{INFLUÊNCIA DOS SISTEMAS DE CONTROLE E DA FOLGA DE TEMPO NA INOVAÇÃO DE PROCESSOS}

\section{RESUMO}

Objetivo: Este estudo analisa a influência dos usos interativo e diagnóstico dos Sistemas de Controle Gerencial (SCG) e da folga de tempo na inovação de processos, em empresas incubadas. 
Originalidade/valor: Características organizacionais são associadas com a inovação de processos em organizações de configuração contemporânea. O estudo traz evidências aos achados contrastantes da literatura dos SCG com a folga de tempo e a inovação de processos.

Design/metodologia/abordagem: Pesquisa de levantamento foi realizada com gestores das empresas listadas nos sites de incubadoras associadas à Associação Nacional de Entidades Promotoras de Empreendimentos Inovadores e se obteve uma amostra de 106 respostas válidas. Para analisar os dados, aplicou-se a técnica de Modelagem de Equações Estruturais. Resultados: Os resultados indicaram que o uso interativo dos SCG promove a folga de tempo no trabalho e o uso diagnóstico inibe sua criação. Porém, a folga de tempo não apresentou associação significativa com a inovação de processos, o que revela um papel disfuncional da folga. $\mathrm{O}$ uso interativo dos SCG apresentou influência significativa na inovação de processos. Conclui-se que o uso interativo prevalece quando a finalidade é promover a inovação de processos, pois favorece contatos entre diferentes níveis hierárquicos e aprendizagem, enquanto o uso diagnóstico evidencia sua relevância ao inibir a criação de folga de tempo, entendida como uma disfunção por não levar à inovação de processos. Isso denota complementaridade dos usos interativo e diagnóstico dos SCG nas empresas incubadas.

\section{PALAVRAS-CHAVE}

Uso diagnóstico. Uso interativo. Sistemas de Controle Gerencial. Folga de tempo. Inovação de processos.

\section{REFERENCES}

Abernethy, M. A., \& Brownell, P. (1999). The role of budgets in organizations facing strategic change: An exploratory study. Accounting, Organizations and Society, 24(3), 189-204. doi:10.1016/S0361-3682(98)00059-2

Agrawal, A., Catalini, C., Goldfarb, A., \& Luo, H. (2018). Slack time and innovation. Organization Science, 29(6), 1056-1073. doi:10.1287/orsc. 2018.1215 
Ashok, M., Narula, R., \& Martinez-Noya, A. (2016). How do collaboration and investments in knowledge management affect process innovation in services? Journal of Knowledge Management, 20(5), 1004-1024. doi:10.1108/ JKM-11-2015-0429

Associação Nacional de Entidades Promotoras de Empreendimentos Inovadores (2017). Lista de associados. Recuperado de http://anprotec.org.br/ site/sobre/associados-anprotec/

Baron, R. M., \& Kenny, D. A. (1986). The moderator-mediator variable distinction in social psychological research: Conceptual, strategic, and statistical considerations. Journal of Personality and Social Psychology, 51 (6), 1173-1182. doi:10.1037//0022-3514.51.6.1173

Beck, F., \& Beuren, I. M. (2015). Folga organizacional: Análise em uma perspectiva comportamental no campo empírico. Revista Universo Contábil, 11 (4), 6-26. doi:10.4270/RUC.2015429

Bisbe, J., \& Malagueño, R. (2009). The choice of interactive control systems under different innovation management modes. European Accounting Review, 18(2), 371-405. doi:10.1080/09638180902863803

Bisbe, J., \& Otley, D. (2004). The effects of the interactive use of management control systems on product innovation. Accounting, Organizations and Society, 29(8), 709-737. doi:10.1016/j.aos.2003.10.010

Bourgeois III, L. J. (1981). On the measurement of organizational slack. Academy of Management Review, 6(1), 29-39. doi:10.2307/257138

Cohen, J. (1988). Statistical power analysis for the behavioral sciences. (2nd ed.). London: Routledge.

Cruz, A. P. C., Frezatti, F., \& Bido, D. S. (2015). Estilo de liderança, controle gerencial e inovação: Papel das alavancas de controle. Revista de Administração Contemporânea, 19(6), 772-794. doi:10.1590/1982-7849rac2015150099

Davila, A., Foster, G., \& Oyon, D. (2009). Accounting and control, entrepreneurship and innovation: Venturing into new research opportunities. European Accounting Review, 18(2), 281-311. doi:10.1080/096381809027 31455

Demartini, C., \& Mella, P. (2014). Beyond feedback control: The interactive use of Performance Management Systems: Implications for process innovation in Italian healthcare organizations. The International Journal of Health Planning and Management, 29(1), 1-30. doi:10.1002/hpm.2177

Faul, F., Erdfelder, E., Buchner, A., \& Lang, A. G. (2009). Statistical power analyses using $G^{*}$ Power 3.1: Tests for correlation and regression analyses. Behavior Research Methods, 41(4), 1149-1160. doi:10.3758/BRM.41.4.1149 
Fávero, L. P., \& Belfiore, P. (2017). Manual de análise de dados: Estatística e modelagem multivariada com Excel®, SPSS ${ }^{\circledR}$ e Stata ${ }^{\circledR}$. São Paulo: Elsevier.

Fornell, C., \& Larcker, D. F. (1981). Evaluating structural equation models with unobservable variables and measurement error. Journal of Marketing Research, 18(1), 39-50. doi:10.2307/3151312

Frezatti, F., Bido, D. S., Cruz, A. P. C., \& Machado, M. J. C. (2017). Impacts of interactive and diagnostic control system use on the innovation process. Brazilian Administration Review, 14(3), 1-24. doi:10.1590/1807-7692bar 2017160087

Guenther, T. W., \& Heinicke, A. (2019). Relationships among types of use, levels of sophistication, and organizational outcomes of performance measurement systems: The crucial role of design choices. Management Accounting Research, 42, 1-25. doi:10.1016/j.mar.2018.07.002

Hackett, S. M., \& Dilts, D. M. (2004). A systematic review of business incubation research. The Journal of Technology Transfer, 29(1), 55-82. doi:10.1023/ B:JOTT.0000011181.11952.0f

Hair Jr., J. F., Hult, G. T. M., Ringle, C., \& Sarstedt, M. (2016). A primer on partial least squares structural equation modeling (PLS-SEM). Los Angeles: Sage.

Henri, J. F. (2006). Management control systems and strategy: A resourcebased perspective. Accounting, Organizations and Society, 31 (6), 529-558. doi:10.1016/j.aos.2005.07.001

Lawson, M. B. (2001). In praise of slack: Time is of the essence. The Academy of Management Executive, 15(3), 125-135. doi:10.1109/EMR.2002.1022400

Lopes, I. F., Beuren, I. M., \& Martins, G. D. (2018). Alinhamento entre uso de instrumentos do sistema de controle gerencial e inovação de produtos e processos. Revista Organizações em Contexto, 14(27), 1-27. doi:10.15603/ 1982-8756/roc.v14n27p1-27

Malagueño, R., \& Bisbe, J. (2010). The role of management accounting and control systems as antecedents of organizational creativity and innovation capabilities. Available at SSRN 1720989. doi:10.2139/ssrn.1720989

Mallidou, A. A., Cummings, G. G., Ginsburg, L. R., Chuang, Y. T., Kang, S., Norton, P. G., \& Estabrooks, C. A. (2011). Staff, space, and time as dimensions of organizational slack: A psychometric assessment. Health Care Management Review, 36(3), 252-264. doi:10.1097/HMR.0b013e318208ccf8

Marlin, D., Geiger, S. W. (2015). A reexamination of the organizational slack and innovation relationship. Journal of Business Research, 68(12), 26832690. doi:10.1016/j.jbusres.2015.03.047 
Naranjo-Gil, D., \& Hartmann, F. (2006). How top management teams use management accounting systems to implement strategy. Journal of Management Accounting Research, 18(1), 21-53. doi:10.2308/jmar.2006. 18.1.21

Nohria, N., \& Gulati, R. (1996). Is slack good or bad for innovation? Academy of Management Journal, 39(5), 1245-1264. doi:10.2307/256998

Organização para a Cooperação e Desenvolvimento Econômico (2005). Manual de Oslo: Diretrizes para coleta e interpretação de dados sobre inovação (3a. ed.). Brasília: Finep.

Podsakoff, P. M., MacKenzie, S. B., Lee, J. Y., \& Podsakoff, N. P. (2003). Common method biases in behavioral research: A critical review of the literature and recommended remedies. Journal of Applied Psychology, 88(5), 879-903. doi:10.1037/0021-9010.88.5.879

Schoute, M., \& Wiersma, E. (2011). The relationship between purposes of budget use and budgetary slack. Advances in Management Accounting, 19(1), 75-107. doi:10.1108/S1474-7871(2011)0000019010

Sharfman, M. P., \& Dean Jr., J. W. (1997). Flexibility in strategic decision making: Informational and ideological perspectives. Journal of Management Studies, 34(2), 191-217. doi:10.1111/1467-6486.00048

Simons, R. (1990). The role of management control systems in creating competitive advantage: New perspectives. Accounting, Organizations and Society, 15(1-2), 127-143. doi:10.1016/0361-3682(90)90018-P

Simons, R. (1995). Levers of control. Cambridge: Harvard Business School.

Simons, R. (2000). Performance Measurement and Control Systems for implementing strategy: Text \& cases. Upper Saddle River: Prentice Hall.

Tan, J. (2003). Curvilinear relationship between organizational slack and firm performance: Evidence from Chinese state enterprises. European Management Journal, 26(6), 740-749. doi:10.2139/ssrn.1552265

Tan, J., \& Peng, M. W. (2003). Organizational slack and firm performance during economic transitions: Two studies from an emerging economy. Strategic Management Journal, 24(13), 1249-1263. doi:10.1002/smj.351

Wåhlberg, A. E., \& Poom, L. (2015). An empirical test of nonresponse bias in internet surveys. Basic and Applied Social Psychology, 37(6), 336-347. doi :10.1080/01973533.2015.1111212

Widener, S. K. (2007). An empirical analysis of the levers of control framework. Accounting, Organizations and Society, 32(7-8), 757-788. doi:10.1016/ j.aos.2007.01.001 
Zhor, S. (2018). Organizational slack resources and innovation adoption process: The moderating effects of Management Control System (MCS). Proceedings of the International Conference on E-Business and Applications (Iceba). doi:10.1145/3194188.3194193

\section{AUTHOR NOTES}

Celliane F. Pazetto, master from the Postgraduate Program in Accounting, Federal University of Santa Catarina (UFSC); Silvana Mannes, graduated from the Accounting Department, Federal University of Santa Catarina (UFSC); Ilse Maria Beuren, Ph.D. from the Faculty of Economics, Administration and Accounting (FEA), University of São Paulo (USP).

Celliane F. Pazetto is now a doctoral student at the Federal University of Santa Catarina (UFSC); Silvana Mannes is now a master's student at the Federal University of Santa Catarina (UFSC); Ilse Maria Beuren is now professor at the Postgraduate Program in Accounting of Federal University of Santa Catarina (UFSC).

Correspondence concerning this article should be addressed to Ilse Maria Beuren, campus Reitor João David Ferreira Lima, s/n, Trindade, Florianópolis, Santa Catarina, Brasil, CEP 88040-970.

E-mail: ilse.beuren@gmail.com

\section{EDITORIAL BOARD}

Editor-in-chief

Gilberto Perez

Associated Editor

Gisela Demo

Technical Support

Vitória Batista Santos Silva

\section{EDITORIAL PRODUCTION}

Publishing Coordination

Jéssica Dametta

Layout Designer

Editorial Intern

Paula Di Sessa Vavlis

Emap

Graphic Designer

Libro

Language Editor

Daniel de Almeida Leão 